\title{
CONSTITUTIONAL JUSTICE
}

\author{
Assistant Anca-Florina Moroșteș PhD \\ Lecturer Narcisa-Mihaela Stoicu PhD \\ „Vasile Goldiș” Westerm University of Arad
}

(Received February 2017; Accepted April 2017)

\begin{abstract}
The paper with the title "Constitutional Justice" aims to analyse a topic of urgent actuality and of particular importance in the contemporary society. We have tried to show in this paper the importance of the Constitutional control in the rule of law. Starting from the idea of necessity of existence of a Constitution in a democratic State and, implicitly, of a body to follow-up the compliance with its provision, we have tried to highlight in this paper the role of Romanian Constitutional Court and not only, by presenting one of its most important attributions which is the control of the law constitutionality.
\end{abstract}

Keywords: justice, court, control, constitutionality, instance

The constitution supremacy is one of the rules of law premises, firstly, being instituted by the control of the constitutionality of the laws. Theorised by Kelsen (1918), the control of the law constitutionality is achieved through a jurisdictional body in the American system and through a unique and specialised body in the European one. The specific literature highlights that both models of constitutionality control of the laws aim for the same goal in the context of the increasing activity of constitutional jurisdiction (Criste, 2017).

The constitutional justice is achieved by constitutional courts (France, Croatia, Hungary, Bulgaria, Italy, Russia, Austria, Slovenia), constitutions courts of law (Spain, Switzerland, Poland, Portugal) or by judicial bodies with attributions also concerning the constitutionality control (USA, Norway, Greece, Cyprus, Finland, Denmark, Sweden). The Constitutional Courts have a role of counterweight between the three State powers; in the meaning that such an institution does not belong to the executive, legislative or judicial power which empowers the constitutional jurisdiction to act "plenipotentiary" on them, in compliance with the letter and the spirit of the fundamental law (Deleanu, 2003).

The purpose of the constitutional bodies is to insure the supremacy of the Constitution. The concept of the supremacy of the Constitution is complex, comprising political and juridical elements reflecting the super-ordinated position of the Constitution, both in the law system and in the political and social systems of a State.

Among the guarantees of the Constitution supremacy, in a harmonious and necessary way for the general control of putting the Constitution into practice, 
there belong the control of the law constitutionality and the fundamental task for everyone to comply with the Constitution provisions. In any rule of law, the control of the law constitutionality becomes a needed warranty of translating into life the constitutional norms and principles, their practical application, the direct achievement of citizens' rights and freedoms. At the same time, this control aims to guarantee the setting up of the separation and balance of the state powers and the consistency with the skills which are conferred to various State bodies. Under such circumstances, it is natural to have a concordance between the law and the fundamental Law and, moreover, it is required to provide the compliance of all legal provisions with the provisions of the fundamental law so that they have to meet an essential requirement of the achievement of the genuine objectives of the rule of law, meaning the warranty for the consistency of the entire normative order in its entirety with the basic norms consecrated by the Constitution as the most important law of the State.

Achieving the position of warrant of the Constitution supremacy, and within their incumbent competencies, the Constitutional Courts ensure the functioning of the constitutional mechanism of the regime of powers separation in the rule of law.

The constitutional courts decide on the constitutionality and legality of the result of the activity of the legislative body, but they cannot create a juridical norm instead of the one ceasing its effects. Consequently, the activity of the institutional courts does not tend to interfere directly with the law-maker's prerogatives in the activity of issuing laws. The attributes of the constitutional bodies are established just as indirect participation in the public authorities' activity, by exerting the control on the legality and constitutionality of the passed acts and by eliminating the juridical norms opposite to the Constitution.

The decisions of the bodies of constitutional contentious may not be invalidated by any state public authority. Although, the entry into force of the decisions for acknowledging the unconstitutionality may be delayed, which is equivalent to granting a deadline for bringing the respective normative act in compliance with the decision of the Court. One of the factors establishing the compulsiveness of the decisions issued by the constitutional justice is precisely the existence of some constants of the jurisprudence of the constitutional bodies.

The efficacy of the constitutional justice is a concern at global scale. There are in practice situations of non-execution of the decisions of the constitutional instances. In order to fight against such phenomena, the constitutional bodies are concerned with the increase of the efficiency of monitoring the decisions and of the improvement of the system for decisions execution.

A comparative exam of the constitutional systems shows that there are two types of organisation of the constitutional justice. The American model of constitutional justice supposes the existence of a diffuse control acknowledged for all bodies, not 
for one body in particular; it is a concrete control, the judge deciding as exception for the laws applying to a private person, and a posteriori control as the control is made on a law in force.

Unlike the American system, the European model supposes the separation of the constitution contentious from all the other forms of contentious. The constitutionality control is performed by a unique and special constitutional body, it is an abstract control as the judge decides on summons against the law, beyond any litigation and it is a priori as the control is performed on a law which is not promoted yet. Actually, we find ourselves in the presence of some ideal models which are not entirely complied with by any concrete system. By itself, the European model is questioned, as we could talk of a diversity of the constitutional justice in Europe, first of all for that the level of abstracting of the constitutional justice varies from one country to another, then for the level of concentration of the European constitutional justice varies also depending on the country (Criste, 2010). The jurisprudence of the Constitutional Courts contributes to spreading the influence of the control system in the coordination of the States' political life; and as such, we wonder if these bodies role is not amplified so it comes to create a genuine jurisdictional policy as well?

For now, we are sure that the constitutional justice gradually won a central position in the system of the liberal institutions of the State by guaranteeing the constitutional balances and by protecting the citizen's rights and freedoms, and so exerting a major influence on the entire political system.

The American model of constitutional justice has been created by jurisprudence, by the Case Marbury vs. Madison, showing them that, when a law is opposite to the Constitution, the courts of law must watch over the compliance of the fundamental act. The control of the constitutionality of the laws is decentralised concrete/ diffuse and posteriori in this model. First, this model has been exported in Latin America, then even in some European countries, during this dissemination process, it has been denatured, especially by becoming concentrated, though remaining under the competence of a court belonging to the common judicial system or by the fact that the notification of the constitutional court may be done only by summons, and not by exception (Criste, 2010).

The European model of control of the constitutionality of the laws is disputed by two juridical orientations. On one hand, the control of the constitutionality of the laws carried on out by a judge is supported by Jellinek, who is in favour of the existence of a specialised central body, apart from the judicial authorities of the State, and, on the other hand, the European model of constitutionality control shaped by Hans Kelsen. In Kelsen's view, the juridical order is likely to a building with more superposed layers, a pyramid or a hierarchy formed by a certain number of levels or of "layers" of juridical acts and norms, the Constitution being on their 
top. The compliance with this hierarchy must be supervised by a unique body, special and specialised in exerting control, a negative legislator who cannot intervene in the legislative work otherwise than by sanctioning the eventual situations of unconstitutionality (Curtin, 2013).

In Romania, with the passing of the Constitution in 1991, the European model of constitutionality control of the laws has been adopted. This is achieved both a priori, prior to the promulgation of the laws, and posteriori, the activity being performed by a special and specialised body, respectively by the Romanian Constitutional Court.

For the good functioning and genuine integration of the constitutional justice in a concrete political system, it is extremely important that it is accepted by all political actors and by those groups succeeding to build a type of comparable and competitive belonging to the national one. The assessment of one system or another of appointment of the members of the constitutional jurisdictions must be made in relation on how it succeeds in a concrete system to reduce the appeals and not depending on a supposed apolitical character. Sometimes, a politicised system may create a more accentuated integration in the system of the constitutional justice compared to another, which, trying to avoid the politicised style, may lead to discontent of the political forces and, thus, to the denial of the legitimacy of the constitutional court.

The appointment of the members of the courts of constitutional contentious supposes in most of the cases to appeal to highest State authorities - head of state and parliamentary chambers, and so giving legitimacy to the jurisdictional activity of the constitutional courts or bodies.

There are three systems known for the appointment of the judges of the courts of constitutional contentious, respectively, the one of appointment, that of elections and the mixed one combining the appointment with the election.

The procedures to accomplish the attributions of the constitutional courts are in a considerable amount similar to the features of the court proceedings, and in the exercise of their attributions, the judges are independent and immovable. For guaranteeing the constitutional judges' independence, it is necessary to provide for a minimum set of rules aiming for the duration of the constitutional judges' mandate, the renewable character of their mandate, the constitutional judges' immovability and immunity, and also on their incompatibilities (Toader, Safta, 2016).

The Constitutional Court of Romania has been structured according to the model of the Constitutional Council of France, being formed by nine judges, elected or appointed for a 9-year mandate which cannot be extended or renewed. Three of the Constitutional Court judges are elected by the Chamber of Deputies, three by the Senate and three judges are appointed by the President of Romania. 
The mandate for the Constitutional Court judges starts on the date of their oath. The Constitutional Court is renewed with one third of its judges every three years according to the terms stipulated by the Constitution (art. 150 par. 2) and by the Law 47/1991, regulating its organisation and functioning.

By secret balloting, the judges of the Constitutional Court elect the president of the Court for a 3-year mandate. For the election of the Court president, each group of judges appointed by the Chamber of Deputies, by the Senate and by the President may submit only one application. The president of the Court is elected with majority of the judges' votes.

This constitutional institution is a first in Romania, an innovation of the 1991 Constitution by the fact that it explicitly received the constitutionality control of the laws. In the previous system, the constitutionality control was incumbent to the socialist Parliament, and in the system of the 1923, belonged to the High Court of Cassation and Justice. The juridical specific literature analysed thoroughly the institution which might be competent to perform the control of the law constitutionality. Thus, in the Constitutive Assembly, there were vivid and vast discussions on the matter. We notice that it was considered either the set-up of a special and specialised body to perform such control, named the Constitutional Council or the Constitutional Court or the return to the 1923 system, to the tradition existing in the field since 1912, respectively to the legal control of the laws constitutionality.

Generally, the Constitutional Courts have the competence to perform a constitutionality control on the acts with normative character, and on the acts with individual character, a constitutionality control on the regulations for Parliament organisation and functioning and a constitutional control on the Government regulations on organisation and functioning in some political systems. The constitutional courts are competent in deciding on the electoral contentious and on the proceedings for public consultation, as well as on the juridical conflicts of constitutional nature.

By considering two criteria, we can classify the constitutional control exerted by the constitutional courts, respectively its location depending on the momentum of promulgation of the law in relation to which we could meet an a priori control and a posterior control, and on its location in relation with the time of implementing the law, according to which we could be in the presence of an abstract or of a concrete control.

The concrete constitutional control is the control performed during a trial or a dispute. It is always a posteriori control. This way of control may have two options, in the meaning that either the matter of the non-constitutionality of the norm is a priori issue to be solved by the competent judge to rule the substance under the control of the higher structure, or it cannot be solved by anyone else than a 
constitutional jurisdiction notified by the summons of either of the parties or by default, by the judging body. The constitutionality control is abstract when the norm itself is criticised and not its implementation in a specific case or situation. The abstract control of the law could be performed a priori or posteriori, and it could be both political, and jurisdictional.

The rightfulness of the parliamentary elections and the acknowledgement of the real will of the system, as well as insuring the direct participation of the electoral body to the exercise of power is achieved differently in the constitutional systems as the constitutional bodies are invested with attributions which guarantee the authenticity of the will expressed by the people.

The contentious on the parliamentary mandate may be considered through the prism of the limits of the exercise of this mandate. In this regard, the constitutional body is sometimes called to decide upon the existence or the absence of incompatibilities between the parliamentary mandate and some public or private positions, and to express the consequences of the existence of such a situation. In addition, the institutional body is called to extract the consequences created by the occurrence of a criminal sanction of forbidding the civil or political rights for a member of the parliament and for guaranteeing the independence of exerting the mandate, as well as the warranty of the parliament member's independence during the mandate.

The proclamation and effective warranty of the human rights is incumbent to the internal juridical regulations for each state, the human rights being meaningless if they are not registered in the constitutions of each state, and so becoming fundamental rights and freedoms, as the human being integrates in a certain socialpolitical system, governed by juridical rules. The protection of the fundamental rights and freedoms implies basic warranties and jurisdictional warranties which found their regulation on the constitutional norms, an important role in the procedural warranties being assigned to the constitutional justice.

The appeal to the constitutional bodies for the exercise of the a priori or a posteriori constitutional control is achieved in several ways, according to the dispositions comprised in the Fundamental Laws. Thus, the constitutional bodies can be notified: upon the initiative of some public authorities or some holders of public positions by submission to the courts of law or by private persons, or there can be by default notification.

The rules on running the ruling procedure in front of the constitutional bodies are usually stipulated in their law on organisation and functioning. In some constitutional systems, these rules are established through an organic law which can be adopted only at the proposition of the Court, even after the mandatory control of its constitutionality, while in other constitutional systems, the rules on the development of the procedure in front of the Courts are included in the Court 
regulations on functioning, which, usually, is adopted by the constitutional body itself.

In some constitutional systems, we can meet decisions expressing the will of the Court as a whole, the decisions being adopted with simple majority, but, as they are presented as the opinion of the entire Court and as separate opinions are not possible, while in other constitutional systems we meet decisions expressing the will of the members' majority, though the dissident opinions are being accepted and published. The decisions of the constitutional bodies produce erga omnes or inter partes litigantes effects in most of the European States except for those regulating the American model of constitutionality control which apply the rule of the judicial precedent.

Some conclusions are drawn in this paper on the achievement of the constitutional justice in Romania, considering besides the organisation and functioning of the constitutional bodies from various constitutional systems also the experts' opinion in the field, and some information and specific elements from the jurisprudence of the Romanian Constitutional Court.

There have been identified constitutional provisions which should be modified in case of review of the fundamental law in the way of: expanding the constitutionality control also on the decisions with normative character issued by the Parliament; of introducing new attributions of the Constitutional Court, respectively of ruling by default on the constitutionality of the decisions issued by the High Court of Cassation and Justice by which the appeals are solved in favour of the law and the cancelation from the article 146 of the letter 1) of the Constitution.

More often than not, the constitutional conflicts caused ample debates on the excessive politicising of the Romanian Constitutional Court, considering the way of appointing the constitutional judges and their mandate which brought in closeup the need for a constitutional reform of the body invested with the exercise of the constitutional control.

We consider that, for the appointment of the constitutional judges, there should be provided a wider and more credible basis of selection of the constitutional judges and the removal of the situations where the selection might cause partisan actions, conflicts of interests.

We do not agree with the opinion expressed in the doctrine according to which the Constitutional Court should be formed only by magistrates, nor with the opinion according to which in the structure of the Constitutional Court there should also be other professional categories, not only legal experts.

We plead for a structure of the Constitutional Court with legal experts only, with an eventual change of the constitutional provisions setting a high limit of seniority for the appointment of the constitutional judges. As for the appointment of the 
constitutional judges, we believe that a future constitutional regulation should stipulate that the constitutional judges are elected by the Parliament in joint sessions with the vote of a qualified majority of two thirds of the deputies and senators, upon the proposition submitted by the President of Romania, the Government and the Supreme Council of Magistracy.

We may conclude that the constitutional justice is a fundamental size of the rule of law and it has to be achieved by a Constitutional Court, as political - jurisdictional public authority which is placed above the scope of the legal, executive or justice powers, its role being to ensure the supremacy of the Constitution, as fundamental Act of the rule of law (Vida, 2011). Nevertheless, the provisions of the art. 142 par. (1) of the Romanian Constitution specifically rule: "The Constitutional Court is the warrant of the Constitution supremacy." Thus, the supremacy of the fundamental Act is of the essence of the rule of law requirements, also representing a juridical reality implying consequences and warranties. We list among the consequences, the differences between the Constitution and the other law, and, not lately but not the least the compliance of the entire law system with the Constitution, and among the warranties, there is the constitutional control.

\section{Bibliografie}

1. Criste M., Drept constituțional.Un drept al statului, Universul Juridic, București, 2017;

2. Curtin, H., Dilemele controlului de constitutionalitate, Incursiune în paradigmele spaţiului euro-american, Rosetti International, Bucureşti, 2013;

3. Deleanu, I., Instituţii şi proceduri constituţionale- în dreptul comparat şi în dreptul român, tratat, C.H.BECK, Bucureşti, 2006;

4. T. Toader, M. Safta, Ghid de admisibilitate la Curtea Constituțională a României, Hamangiu, București, 2016;

5. I. Vida, I., Curtea Constituţională a României, Justiţia politicului sau politica justiţiei?, Monitorul Oficial, Bucureşti, 2011. 